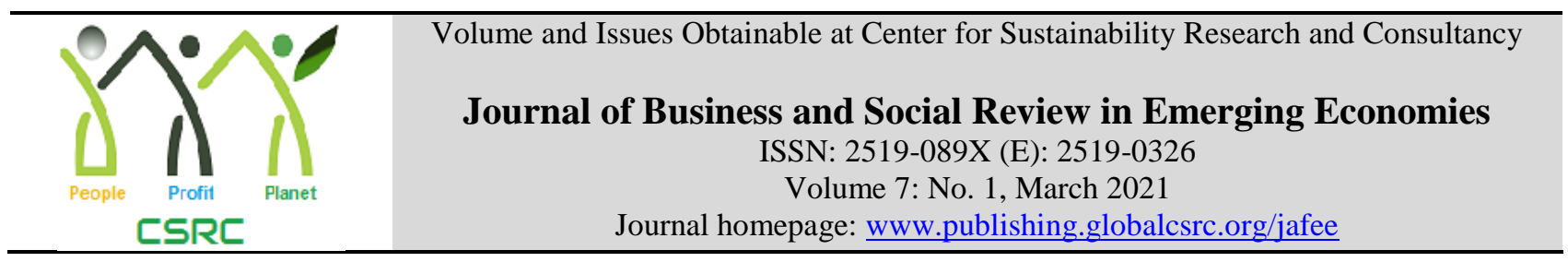

\title{
Role of Mobile Technology in Vocabulary Development of Students with Hearing Impairment
}

\begin{abstract}
*Muntaha Ahmad, Department of Special Education, University of the Punjab, Lahore, Pakistan Ghulam Fatima, Institute of Education and Research, University of the Punjab, Lahore, Pakistan Misbah Malik, Institute of Education and Research, University of the Punjab, Lahore, Pakistan
\end{abstract}

*Corresponding author's email address: muntahaahmad068@gmail.com

\begin{tabular}{l} 
ARTICLE DETAILS \\
\hline History \\
Revised format: Feb 2021 \\
Available Online: Mar 2021 \\
\hline Keywords \\
Mobile technology, \\
Vocabulary Development, \\
Students with hearing \\
impairment.
\end{tabular}

\section{JEL Classification:}

$M 1, M 2$

\section{ABSTRACT}

Purpose: The purpose of this quantitative research was to identify the role of mobile technology in the vocabulary development of students with hearing impairment.

Methodology: The population of study involved students with hearing impairment from schools in Lahore. A sample of 80 students studying at National Special Education Center, Johar Town Lahore, and Govt. Degree College of Special Education, Lahore was selected studying from 7 th grade to bachelors. A self-developed and validated questionnaire was used to elicit students` responses on the usage of mobile technology in the aspect of reading, writing, social media and grammar and punctuation skills. Data was collected personally by going to the institutions and distributing the questionnaires among students. A sign language interpreter translated the questions in sign language and the students gave appropriate answers. The collected data was analysed on SPSS. Independent sample t-test was used to see differences in the vocabulary development based on the usage, age, gender, and grade of the students.

Findings: Major findings revealed that mobile technology is playing a significant role in learning vocabulary among students with hearing impairment. It has played a major role in learning new words and connecting with the world more quickly.

Implications: This technology should be used for academic purposes to improve their language skills and bridge the communication gap. Conclusions were drawn and recommendations to Punjab Special Education Department of Pakistan were made.

(C) 2021 The authors, under a Creative Commons AttributionNonCommercial 4.0

Recommended citation: Ahmad, M., Fatima, G. \& Malik, M. (2021). Role of Mobile Technology in Vocabulary Development of Students with Hearing Impairment. Journal of Business and Social Review in Emerging Economies, 7(1), 159-165.

\section{Introduction}

Language development plays a significant role in the academics and daily life of a child with hearing impairment. The child may solely depend on sign language but to communicate in this world he needs to 
improve his national or international language to excel in practical life. In most educational jurisdictions, special education is governed by federal law. Under the Individuals with Disabilities Education Act (2017), Special Education is defined as: "Specially designed instruction, at no cost to parents, to meet the unique needs of a child with a disability." The Individuals with Disabilities Education Act (IDEA) gave the following official definition of hearing impairment "an impairment in hearing, whether permanent or fluctuating, that adversely affects a child's educational performance but is not included under the definition of 'deafness (Watson, 2018)."

Due to diminished auditory response to sound a student or child with hearing disabilities or deafness has deficits in language and speech development. Students demonstrate different degrees of hearing loss which results in difficulty acquiring spoken language very often. According to World Health Organization (2020), approximately out of 466 million world population, 5\% persons are having hearing impairment including 432 million adult population and 34 million minors. It is guessed that there will be one person with hearing loss in every 10 people in 2050 or there will be above 900 million persons with hearing impairment. Hearing loss greater than 40 decibles $(\mathrm{dB})$ in the better ear in adult population and more than 30 decibles $(\mathrm{dB})$ in children is known as disabling hearing loss. Many persons with this type of hearing loss belong to third world countries. Almost 1/3 persons above 65 years of age are having disabling hearing impairment. The countries of Asia Pacific, South Asia and Sub-Saharan Africa are having the greatest number of 65 years old persons with this disability condition (World Health Organization, 2020).

On April 3, 1973, Martin Cooper, who was an engineer at Motorola company rang a competitive company of telecommunications through mobile phone for the first time and told them that this call was being made through a mobile phone. The phone used by Martin Cooper weighed an amazing 1.1 kilograms and its measurement was $228.6 \times 127 \times 44.4 \mathrm{~mm}$. this model mobile phone's charging time was 10 hours and it was having half an hour talk time.Smartphones have become our inseparable companions today, and they are not relatively new. The history of mobile phones goes back to 1908 when a US Patent was issued for a wireless telephone in Kentucky. Mobile phones were invented as early as the 1940s when engineers working at AT\&T developed cells for mobile phone base stations (Seward, 2013).

Vocabulary, in a specific language, is a word which is familiarized to a man. Vocabulary is developed increasingly with the passage of time. It is thought to be an important source of communication that assists in the development of knowledge. Vocabulary helps a person in the acquisition of knowledge, development of spontaneous communication and in maintaining social relationships. It is considered a group of words which are organized in an order and used by a person for a specific topic. Mobile technology is used for learning a language. It originates from mobile learning (m Learning) and can be seen as a specialization of that field (Viberg \& Grönlund, 2013)." Crompton (2013) defines mobile learning as the "learning across multiple contexts, through social and content interactions, using personal electronic devices."

\section{Objectives of the Study}

This study was carried out to discover the effectiveness of mobile technology in vocabulary learning. The intention of this study was also to shed light on the interest of students with hearing impairment in vocabulary learning through mobile phone and the role of mobile applications in academic vocabulary development.

\section{Methodology}

The study was quantitative in nature. The population of this research consisted of all the students having hearing problem studying in the schools of Lahore. The sample of the study included 80 students from the National Special Education Center, Johar Town Lahore, Pakistan and Government Degree College of Special Education, Lahore, Pakistan. The data was gathered from students through a questionnaire 
which was developed by the researchers comprising two parts. Part one included demographic characteristics of the students including the name of the student (optional), gender, age, grade, and name of the institution they were studying in. The basic intention of collecting this information was to understand the characteristics of the sample. The second part of the questionnaire consisted of four subscales: 1. Reading (statement 1- 5), 2. Social Media (6- 11), 3. Writing (12- 16), 4. Grammar and Punctuation Skills (17-24). All statements (1-24) were on three points (Yes, To Some Extent, No) Likert scale. The validity of the instrument was made sure by gathering opinions of eighty students based on their experience with mobile devices in their life. Reliability of the instrument was fixed with the help of piloting (Cronbach alpha= 0.92).

\section{Procedure Adopted for Collection of Data}

The first step was to take the permission of the two principals of the institutions for collecting data from students by writing a permission letter signed by the head of our department, and our supervisor. They were briefed about the purpose and details of the study. After seeking the permission in writing, the respective special education teachers dealing with students with hearing impairment from grade $7^{\text {th }}$ till BA were reached out and asked for assistance in the filling of the questionnaires. Data was collected from $80(100 \%)$ students in person. It took almost seven days in collecting back the filled in questionnaires from the students. The return rate was $100 \%$.

\section{Findings}

The results in the forms of tables and interpretations are presented as follows:

Table 1

Demographic characteristics of the sample

\begin{tabular}{|c|c|c|c|}
\hline \multirow{4}{*}{ Gender } & Demographics & Frequency & Percentage \\
\hline & Male & 48 & 60.0 \\
\hline & Female & 32 & 40.0 \\
\hline & Total & 80 & 100.0 \\
\hline \multirow{3}{*}{ Age } & $15-20 y r s$ & 61 & 76.2 \\
\hline & $21-25 y r s$ & 19 & 23.8 \\
\hline & Total & 80 & 100.0 \\
\hline \multirow{2}{*}{$\begin{array}{l}\text { Qualification } \\
\text { Respondents }\end{array}$} & Elementary & 14 & 17.5 \\
\hline & Secondary & 19 & 23.8 \\
\hline
\end{tabular}




\begin{tabular}{|c|c|c|c|}
\hline & Higher Secondary & 38 & 47.5 \\
\hline & Bachelors & 9 & 11.2 \\
\hline & Total & 80 & 100.0 \\
\hline \multirow{3}{*}{ Institutions } & $\begin{array}{lr}\text { National } & \text { Special } \\
\text { Education } & \text { Center } \\
\text { Lahore } & \end{array}$ & 33 & 41.2 \\
\hline & $\begin{array}{l}\text { Govt. Degree } \\
\text { College of Special } \\
\text { Education Lahore }\end{array}$ & 47 & 58.8 \\
\hline & Total & 80 & 100.0 \\
\hline
\end{tabular}

Table 1 shows that $48 \%$ respondents were male and $32 \%$ respondents were female, $76 \%$ of the respondents were between 15-20 years and 24\% of the respondents were 21-15 years old. Moreover, 8\% of respondents were from elementary level, $24 \%$ were from secondary level, $48 \%$ of respondents were from higher secondary level and $11 \%$ respondents were from Bachelors. In the same way, $41 \%$ respondents were from National Special Education Centre, Lahore, Pakistan and 59\% were from Government Degree College of Special Education Lahore, Pakistan.

Table 2

Frequency distribution of students' responses

\begin{tabular}{|c|c|c|c|c|}
\hline $\begin{array}{l}\text { Sr. } \\
\text { No }\end{array}$ & Statements & Yes & $\begin{array}{l}\text { To } \\
\text { some } \\
\text { extent }\end{array}$ & No \\
\hline \multicolumn{5}{|c|}{ Reading } \\
\hline 1. & I use a mobile device (i.e., smartphone, tablet, iPad etc.) on daily basis. & $80 \%$ & $1.2 \%$ & $18.8 \%$ \\
\hline 2. & I use my mobile phone for studying purpose. & $77.5 \%$ & $7.5 \%$ & $15.0 \%$ \\
\hline 3. & Mobile technology helps me solve study related problems. & $71.2 \%$ & $16.2 \%$ & $12.5 \%$ \\
\hline 4. & I use my phone for reading. & $55 \%$ & $20 \%$ & $25 \%$ \\
\hline 5. & $\begin{array}{l}\text { I use mobile phone for translating into sign language for better } \\
\text { understanding. }\end{array}$ & $56.2 \%$ & $40.0 \%$ & $3.8 \%$ \\
\hline
\end{tabular}

\section{Social Media}

\begin{tabular}{l|lllll}
\hline 6. & I use social media applications (i.e., Facebook, WhatsApp, Twitter etc.) & $82.5 \%$ & $11.2 \%$ & $6.2 \%$
\end{tabular} to connect with friends. 


\begin{tabular}{|c|c|c|c|c|}
\hline 7. & I use my mobile phone for text messaging. & $85.0 \%$ & $12.5 \%$ & $2.5 \%$ \\
\hline 8. & Texting with friends helps me improve my language. & $78.8 \%$ & $15.0 \%$ & $6.2 \%$ \\
\hline 9. & Text messages help me learn new words. & $67.5 \%$ & $18.8 \%$ & $13.8 \%$ \\
\hline 10. & I come across new words often when I scroll through my social media. & $55.0 \%$ & $38.8 \%$ & $6.2 \%$ \\
\hline 11. & I search a new word that catches my attention on the phone. & $55.0 \%$ & $13.8 \%$ & $31.2 \%$ \\
\hline
\end{tabular}

\section{Writing/Typing}

\begin{tabular}{|c|c|c|c|c|}
\hline 12. & I use a word prediction tool on my keyboard. & $71.2 \%$ & $6.2 \%$ & $22.5 \%$ \\
\hline 13. & Word prediction tool helps me memorize/learn new words. & $58.8 \%$ & $28.8 \%$ & $12.5 \%$ \\
\hline 14. & I used mobile dictionaries to search meaning of words. & $60.0 \%$ & $31.2 \%$ & $8.8 \%$ \\
\hline 15. & I ask someone meaning of a new word that I see on my phone. & $58.8 \%$ & $35.0 \%$ & $6.2 \%$ \\
\hline 16. & Usage of mobile phone has improved my language. & $51.2 \%$ & $36.2 \%$ & $12.5 \%$ \\
\hline
\end{tabular}

\section{Grammar and Punctuation Skills}

\begin{tabular}{|c|c|c|c|c|}
\hline 17. & $\begin{array}{l}\text { Using a mobile phone has helped me improve my sign language and } \\
\text { English vocabulary. }\end{array}$ & $77.5 \%$ & $18.8 \%$ & $3.8 \%$ \\
\hline 18. & I use my mobile phone to learn the correct punctuation. & $62.5 \%$ & $33.8 \%$ & $3.8 \%$ \\
\hline 19. & I use spell checker to correct the spellings of words. & $48.8 \%$ & $31.2 \%$ & $20 \%$ \\
\hline 20. & Mobile technology helps me improve my grammar skills. & $60.0 \%$ & $20.0 \%$ & $20.0 \%$ \\
\hline 21. & Watching videos with subtitles helps me learn new words. & $65.0 \%$ & $15.0 \%$ & $18.8 \%$ \\
\hline 22. & I learn new words through mobile games. & $50.0 \%$ & $41.2 \%$ & $8.8 \%$ \\
\hline 23. & Use of mobile phones in our language class will be very helpful. & $72.5 \%$ & $13.8 \%$ & $13.8 \%$ \\
\hline 24. & $\begin{array}{l}\text { The words I learn through my mobile phone stay in my memory } \\
\text { longer. }\end{array}$ & $56.2 \%$ & $38.8 \%$ & $5.0 \%$ \\
\hline
\end{tabular}

Table 2 depicts the percentages on the number of students who responded to each statement. Majority of the students responded positively and agreed that using mobile phone helps them learn new words more quickly. Most of the students also agreed that English words sit in their minds more quickly than Urdu 
words and they prefer to study in English because they use English in their mobile phones as well.

\section{Discussion}

This research was conducted to find out the role of mobile technology in vocabulary development of students with hearing impairment in the aspects of reading, writing, grammar and communication. The results of this study portray that mobile technology is playing significant role in the vocabulary development of students with hearing impairment. This research focused on various applications of mobile technology, which portrays that mobile technology is playing guided role in vocabulary learning of hearing-impaired students.

It was through this study that we found out that students who use mobile phones in their daily life are quicker to grasp and learn new words because they are most likely to use those words in their texting or scrolling through social media. Students agreed that using mobile technology in the academics will make language learning much easier for them.

This study proves that in this era of mobile technology, when the world is progressing much faster and heavily relies on communication and technology, more focus should be paid in teaching students with hearing impairment by using modern technology. We should take measures in the development of educational methods for teaching students with hearing impairments and help them bridge the gap of communication between them and the modern world through modern means of technology.

\section{Recommendations}

On the basis of findings of this research, following recommendations are given by the researchers:

1. Special mobile applications should be designed which will help hearing impaired students in vocabulary development. These applications should be easily available on Google Play store and Apples Apps.

2. Government or non-governmental organizations should facilitate the usage of mobile devices (iPad, tablet, PC) in language classrooms of students with hearing impairment to make the language learning process easier, productive, and creative.

3. Such software and applications should be designed and introduced which will make language learning easier in classroom and can be accessed by students easily at home.

4. Language learning labs should be modified and well equipped with recent technology that may speed up the language learning process.

5. Students should be encouraged to use their mobile phones for educational purposes.

6. Workshops should be conducted by schools for children with hearing impairment to guide them how the phone applications can help them in their language learning.

\section{References}

Betsworth, D. G. (1999). Accuracy of self-estimated abilities and the relationship between self-estimated abilities and realism for women. Journal of Career Assessment, 7(1), 35-43.

Couch, J. V., \& Sigler, J. N. (2001). Gender perception of professional occupations. Psychological Reports, 88(3), 693-698.

Lent, R. W., Brown, S. D., \& Hackett, G. (1994). Toward a unifying social cognitive theory of career and academic interest, choice, and performance. Journal of vocational behavior, 45(1), 79-122.

Livneh, H. (1982). On the origins of negative attitudes towards people with disabilities. Rehabilitation literature.

MacLeod-Gallinger, J. E. (1992). The career status of deaf women: A comparative look. American Annals of the Deaf, 137(4), 315-325. 
Mitra, B., Basu Roy, A., Das, A., Shah, S. K., Baidya, S., \& Roy Chaudhury, D. (2018). Insect faunal diversity of Chintamani Kar Bird Sanctuary and other protected areas of West Bengal. Int. Jour. Ent. Res, 3(2), 180-189.

Nelson-Le Gall, S., Kratzer, L., Jones, E., \& DeCooke, P. (1990). Children's self-assessment of performance and task-related help seeking. Journal of Experimental Child Psychology, 49(2), 245-263.

Parasnis, I., Samar, V. J., \& Mandke, K. (1996). Deaf adults' attitudes toward career choices for deaf and hearing people in India. American annals of the deaf, 141(5), 333-339.

Parasnis, I., Samar, V. J., Bettger, J. G., \& Sathe, K. (1996). Does deafness lead to enhancement of visual spatial cognition in children? Negative evidence from deaf nonsigners. The Journal of Deaf Studies and Deaf Education, 1(2), 145-152.

Robison-Awana, P., Kehle, T. J., \& Jenson, W. R. (1986). But what about smart girls? Adolescent selfesteem and sex role perceptions as a function of academic achievement. Journal of Educational Psychology, 78(3), 179.

Rojewski, J. W. (1996). Educational and occupational aspirations of high school seniors with learning disabilities. Exceptional Children, 62(5), 463-476.

Sela, I., \& Weisel, A. (1992). The deaf community in Israel. Tel Aviv, Israel: Association of the Deaf in Israel, National Insurance Institute, JDC Israel, Ministry of Labour and Welfare.

Swanson, J. L., \& Lease, S. H. (1990). Gender differences in self- ratings of abilities and skills. The career development quarterly, 38(4), 347-359.

Thiessen, V., \& Blasius, J. (2002). The social distribution of youth's images of work. Canadian Review of Sociology/Revue canadienne de sociologie, 39(1), 49-78.

Tilleczek, K. C., \& Lewko, J. H. (2001). Factors influencing 